\title{
Polskie i unijne tendencje regulacyjne po transformacji ustrojowej w Polsce a rola banków spółdzielczych na współczesnym rynku finansowym - przyczynek do dyskusji
}

\section{Wprowadzenie}

Banki spółdzielcze są najliczniejszą grupą banków działających w Polsce¹. Od momentu transformacji ustrojowej, której skutkiem była zmiana w podejściu do całego systemu bankowego, sektor spółdzielczy przeszedł ogromne przeobrażenia, poczynając od jego organizacji, poprzez wzmocnienie kapitałowe, kończąc na koncepcji roli, jaką powinien pełnić na współczesnym rynku finansowym.

Obecnie funkcjonujący model sektora i działalności banków spółdzielczych jest zatem w dużej mierze wynikiem działań legislacyjnych podejmowanych przez prawodawcę polskiego, próbującego go ukształtować w nowych warunkach, ale w pewnym stopniu i unijnego. Ważnym czynnikiem była także aktywność i determinacja samych banków, a dokładniej ich władz, które dążyły do restrukturyzacji sektora czasem wbrew oczekiwaniom legislatora, wymuszając respektowanie ich prawa do określenia własnej drogi rozwoju. Analizując zakres zmian wprowadzanych na szczeblu krajowym i europejskim, wskazać można, że zachodziły one zarówno w sferze prawa publicznego, jak i prywatnego. Antycypując w pewnym stopniu dalsze rozważania, podkreślić trzeba, że prawodawca unijny koncentrował swe wysiłki na wzmocnieniu kapitałowym sektora bankowego jako całości, poprzez wprowadzanie wymogów w zakresie wysokości i struktury funduszy własnych banków oraz zapewnienie właściwego poziomu ochrony kon-

* Dr Anna Zalcewicz - Katedra Prawa Finansów Publicznych, Europejska Wyższa Szkoła Prawa i Administracji w Warszawie.

${ }^{1}$ Zgodnie z danymi Komisji Nadzoru Finansowego, na dzień 11 listopada 2011 r. w Polsce działało 579 banków spółdzielczych na 48 zorganizowanych w pozostałych formach organizacyjno-prawnych (przy czym z tych 48 banków dwa to banki zrzeszające banki spółdzielcze, tj. Bank Polskiej Spółdzielczości SA w Warszawie (dalej: BPS) i SGB-Bank SA w Poznaniu). 
sumentom, natomiast krajowy - na wzmocnieniu kapitałowym i nadaniu nowego kształtu sektorowi banków spółdzielczych. Ten ostatni wdrażał także przepisy wspólnotowe, a następnie unijne, w związku z podjętymi na szczeblu międzynarodowym zobowiązaniami.

Na tle tych wstępnych uwag można sobie postawić pytania: Jak zmieniło się prawo bankowe regulujące działalność banków spółdzielczych? Jak w związku z tym przeobraził się sektor? Jaką rolę mogą pełnić czy pełnią banki spółdzielcze dziś? Po drugie: jaka jest ich funkcja zarówno na krajowym rynku finansowym, jak i unijnym jako całości? Czy są elementem destabilizującym, czy wręcz przeciwnie - stabilizującym sektor bankowy? W poszukiwaniu odpowiedzi na te pytania zostanie dokonana analiza przepisów prawa, zgodnie z tematem zakreślonym w niniejszym opracowaniu, $\mathrm{z}$ punktu widzenia tendencji regulacyjnych prawodawców, unijnego i krajowego, przejawiających się w podejmowanych działaniach legislacyjnych. Przedstawione w referacie rozważania, jak to ujęto w temacie, nie mają na celu wyczerpującego omówienia problemu, co nie byłoby możliwe ze względu na rozmiar opracowania, a mają raczej przyczyniać się do dyskusji nad uwarunkowaniami i kierunkami rozwoju banków spółdzielczych na polskim rynku finansowym.

\section{Bank spółdzielczy jako bank lokalny}

Banki spółdzielcze wykształciły się jako organizacje samopomocowe z konieczności zaspokojenia potrzeb finansowych tej części społeczeństwa, która pozostawała poza obszarem zainteresowania innych instytucji finansowych. W związku z tym można powiedzieć, iż były to jedne z pierwszych podmiotów, które przeciwdziałały, jak to się współcześnie określa, wykluczeniu finansowemu. Pomimo upływu lat, ogromnych zmian społecznych, postępu gospodarczego i technicznego, problem ten jest wciąż żywy i zjawisko to jest nadal obecne. Wydaje się zatem, że w sposób naturalny to właśnie banki spółdzielcze powinny podejmować działania i być adresatem programów realizowanych przez państwo, zapobiegających takiemu wykluczeniu. Aspekt działalności banków spółdzielczych jako banków lokalnych, działających na rzecz społeczeństwa lokalnego może być rozpatrywany nie tylko w wymiarze aktywności na rzecz integracji finansowej poszczególnych jego członków, ale także obsługi bankowej całej społeczności. Z tego punktu widzenia może on być postrzegany z jednej strony jako bank członków gminy, powiatu, do czego predysponowałaby go znajomość realiów i potrzeb rynku lokalnego, jak i bank jednostek samorządu terytorialnego. $\mathrm{Z}$ drugiej strony lokalność pojmowana jest jako działalność na stosunkowo niewielkim obszarze, czego przyczyny upatrywać należy właśnie w ukierunkowaniu usług na rzecz niewielkich społeczności.

Dokonując oceny przepisów prawnych w tym zakresie, wskazać można, że brak jest rozwiązań systemowych. Od momentu rozpoczęcia zmian ustrojo- 
wych problem obszaru działania banków spółdzielczych nie został definitywnie przesądzony. Początkowo (tj. w chwili wejścia w życie ustawy p.b.1989²), zgodnie z postanowieniami swoich statutów, wykonywały one czynności bankowe w ograniczonym, zarówno przedmiotowo, jak i terytorialnie, zakresie. Jednakże na mocy decyzji Banku Gospodarki Żywnościowej (BGŻ) owo ograniczenie zostało zniesione poprzez zmiany w statutach. Tym samym z podmiotów o lokalnym zasięgu działania i zawężonym zakresie świadczonych usług bankowych stały się one samodzielnymi, pełnoprawnymi uczestnikami rodzącej się gospodarki rynkowej. Następnie, uznając konieczność wsparcia legislacyjnego procesu przekształceniowego w sektorze, uchwalono ustawę restrukturyzacyjną ${ }^{3}$. Wyznaczyła ona nowe zasady funkcjonowania banków spółdzielczych, tworząc trójstopniową strukturę zrzeszeniową ${ }^{4}$ oraz wprowadzając rozwiązania służące wzmocnieniu finansowemu spółdzielczego sektora bankowego (obligatoryjna przynależność do właściwego miejscowo banku regionalnego i związków rewizyjnych, powrót do lokalnego charakteru banków poprzez ograniczenia terytorialne ich działalności). Kolejna, obecnie obowiązująca ustawa ${ }^{5}$ zawiera natomiast rozwiązania wskazujące, że aspekt lokalności w działaniu banków spółdzielczych przestał odgrywać istotną rolę, co prawda, terytorialnym ograniczeniom podlegają zrzeszone banki spółdzielcze. Im niższe są ich fundusze własne, tym zasięg terytorialny ich działania jest mniejszy. Niemniej jednak prawodawca nie wiąże ściśle działalności banku z administracyjnymi granicami jednostek samorządu terytorialnego (JST). Dodatkowo, procesy konsolidacyjne, wymuszone koniecznością wypełnienia norm nakazujących w ustawowych terminach osiągnięcie odpowiedniego poziomu funduszy własnych, sprawiły, że rzeczywiste terytorium działalności wyznaczane jest w pewnej mierze w sposób przypadkowy. Odnosząc się do banku działającego poza zrzeszeniem, to o obszarze tym decyduje także wielkość funduszy własnych ${ }^{6}$, może być ona prowadzona na terenie całego kraju, ale także poza jego granica$\mathrm{mi}^{7}$. Jednocześnie prawodawca unijny normatywnie określił minimalny obszar

${ }^{2}$ Ustawa z dnia 31 stycznia 1989 r. Prawo bankowe, Dz. U. Nr 4, poz. 21 ze zm. (dalej: p.b.1989).

${ }^{3}$ Ustawa z dnia 24 czerwca 1994 r. o restrukturyzacji banków spółdzielczych i Banku Gospodarki Żywnościowej oraz o zmianie niektórych ustaw, Dz. U. Nr 80, poz. 369 ze zm.

${ }^{4}$ Bank spółdzielczy (dalej: b.s.) - banki regionalne zrzeszające b.s. oraz bank krajowy (BGŻ SA) zrzeszający banki regionalne.

${ }^{5}$ Ustawa z dnia 7 grudnia 2000 r. o funkcjonowaniu banków spółdzielczych, ich zrzeszaniu się i bankach zrzeszających, Dz.U. Nr 119, poz. 1252 ze zm. (dalej: u.f.b.s.).

${ }^{6}$ Musi wynosić minimum 5 mln euro i tak jak w przypadku każdego innego banku być dostosowana do rodzaju czynności bankowych przewidzianych do wykonywania i rozmiaru zamierzonej działalności.

7 Choć redakcja przepisu może budzić pewne wątpliwości, co do intencji prawodawcy. Zgodnie $\mathrm{z}$ art. 5 ust. $1 \mathrm{~b}$ u.f.b.s., b.s. posiadający fundusze własne równe lub wyższe niż równowartość 5 mln euro może prowadzić działalność na obszarze całego kraju. Mogłoby się bowiem rodzić pytanie, czy nie jest to maksymalny obszar działania. 
działania każdej tzw. spółdzielni europejskiej (SCE). Oznacza to, że w przypadku banku spółdzielczego działającego jako SCE działalność ta musiałaby być prowadzona co najmniej na terytorium dwóch państw - członków UE ${ }^{8}$.

Kolejną kwestią są rozwiązania prawne dla bankowych instytucji samorządu terytorialnego. Obecnie brak jest regulacji prawnych pozwalających na ich tworzenie. Zatem jakkolwiek problem utworzenia banku samorządowego jest dyskutowany od dawna ${ }^{9}$, a na potrzebę jego istnienia wskazują inicjatywy podejmowane przez organizacje samorządowe ${ }^{10}$, nie jest on prawnie regulowany. W przypadku banku spółdzielczego wskazać należy, że prawodawca wyraźnie wyłącza możliwość ich powołania przez JST (założycielami mogą być bowiem wyłącznie osoby fizyczne), choć część JST posiada udziały w tego typu bankach. Natomiast same banki spółdzielcze mogą kierować ofertę do JST, dostosowując ją do potrzeb i oczekiwań lokalnych władz i społeczności, aczkolwiek konieczne jest uwzględnienie także przepisów publicznoprawnych regulujących tę sferę współpracy między JST a bankami ${ }^{11}$.

Ostatnim z omawianych zagadnień w tym kontekście jest problem ukierunkowania świadczenia usług na rzecz mieszkańców zamieszkujących na obszarze działania banku spółdzielczego. Przepisy prawne nie odnoszą się obecnie do idei samopomocowych i analizując je na szczeblu krajowym, wskazać trzeba, że brak jest regulacji określających zadania czy rolę banków spółdzielczych w omawianym obszarze. Muszą one same wypełnić treścią ogólną formułę prawa spółdzielczego $^{12}$, poszukując znaczenia zwrotu „,w interesie członków spółdzielni” z uwzględnieniem regulacji prawa bankowego, które nie zezwalają na preferencyjny sposób traktowania członków b.s. Możliwe jest zatem jedynie przygotowywanie odpowiedniej oferty kierowanej do lokalnej społeczności czy grup społecznych, zawodowych etc. Można na przykład wskazać na usługi dla lokalnych przedsiębiorców, na umowy podpisane $\mathrm{z}$ urzędami gmin na obsługę wypłat socjalnych. Wydaje się zatem, że banki spółdzielcze mogą przyczyniać się zarówno do wspierania lokal-

${ }^{8}$ Zob. szerzej: A. Zalcewicz, Bank spółdzielczy jako Spółdzielnia Europejska-analiza prawna wybranych zagadnień w odniesieniu do regulacji polskich, „Przegląd Ustawodawstwa Gospodarczego" 2008, nr 10, s. 13-23.

$9 \mathrm{Na}$ temat zalet funkcjonowania banków samorządowych i problemów prawnych z tym związanych zob. A. Borodo, Zakres działalności gospodarczej samorzadu terytorialnego i zagadnienie banków samorzadowych, „Gdańskie Studia Prawnicze” 2007, t. XVI, s. 129-138.

${ }^{10} \mathrm{Na}$ przykład obecnie Związek Powiatów Polskich podjął działania mające pozwolić na utworzenie banku, którego właścicielami będą samorządy, zob. m.in. A. Kowalczyk, Samorządy chca banku, „Rzeczpospolita” z 25 stycznia 2012 r.

${ }^{11}$ Chodzi tu np. o przestrzeganie przepisów o zamówieniach publicznych czy ustawy o finansach publicznych, zob. m.in. W. Srokosz, Publicznoprawne ograniczenia kredytowania jednostek samorzadu terytorialnego, „Monitor Prawa Bankowego” 2011, nr 11, s. 41-50.

12 Ustawa z dnia 16 września 1982 r. Prawo spółdzielcze, Dz. U. Nr 30, poz. 210 ze zm., która określa cel działalności spółdzielni jako prowadzenie wspólnej działalności gospodarczej w interesie członków spółdzielni. 
nego rozwoju gospodarczego, jak i walki z wykluczeniem finansowym etc. Niemniej prawodawca polski nie tworzy w tym względzie szczególnych rozwiązań prawnych umożliwiających realizację takich projektów. W tym kontekście wskazać trzeba, że na szczeblu unijnym od kilku lat dyskutowany jest problem wykluczenia finansowego, gdzie jednak podkreśla się znaczną rolę państwa w kształtowaniu polityki i wprowadzaniu instrumentów przeciwdziałania temu zjawisku, nie przesądzając o tym, które z podmiotów rynku finansowego są najbardziej odpowiednimi do realizacji zadań w tym obszarze ${ }^{13}$. Na gruncie przepisów finansowego prawa unijnego jedyną, bezpośrednio nakierowaną na walkę z nim inicjatywą w tym zakresie jest zalecenie w sprawie dostępu do zwykłego rachunku płatniczego ${ }^{14}$. Rekomendowane są $\mathrm{w}$ nim zasady, jakie powinny być przyjęte $\mathrm{w}$ każdym państwie UE w celu zapewnienia możliwie największego stopnia włączenia finansowego w zakresie usług płatniczych. Jednocześnie przyjmuje się, że państwa UE powinny mieć możliwość wyznaczenia - w oparciu o zasady przejrzystości, niedyskryminacji i proporcjonalności - jednego, kilku lub wszystkich dostawców usług płatniczych odpowiedzialnych za zapewnianie dostępu do zwykłych rachunków płatniczych. Możliwe jest zatem przyjęcie na szczeblu krajowym regulacji prawnych włączających właśnie banki spółdzielcze w zakres działań państwa, służących szeroko pojętemu włączeniu finansowemu ${ }^{15}$.

\section{Bank spółdzielczy jako uczestnik rynku finansowego}

Bank spółdzielczy, jak wynika to z obecnie obowiązującej definicji legalnej, jest przede wszystkim bankiem, a dopiero w dalszej kolejności spółdzielnią. Przepis art. 2 pkt 1 u.f.b.s. w sposób pośredni rozstrzyga zatem także o pierwszeństwie stosowania norm prawa bankowego przed prawem spółdzielczym. Przedmiotem analizy tej części artykułu będzie w związku z tym ta część prawa finansowego, która odnosi się do reguł podejmowania i prowadzenia działalności bankowej, ale poprzez pryzmat funkcjonowania banków spółdzielczych.

${ }^{13}$ Wskazuje się, że mogą to być zarówno b.s.-y, podmioty związane z rynkiem usług pocztowych, jak i organizacje non-profit. Przy czym niektóre z krajów UE już 20 lat temu wprowadzały rozwiązania mające sprzyjać integracji społecznej w tym obszarze, zob. raport Financial services provision and prevention of financial inclusion, European Commission, March 2008.

${ }_{14}$ Zalecenie 2011/442/UE Komisji Europejskiej z 18 lipca 2011 r. w sprawie dostępu do zwykłego rachunku płatniczego, Dz. Urz. UE L 190 z 21 lipca 2011 r., s. 87.

15 Tym bardziej, że obecnie nie istnieją żadne sektorowe wytyczne odnośnie pomocy państwa w zakresie usług finansowych dotyczących usług świadczonych w ogólnym interesie gospodarczym i pomoc udzielana w tym zakresie była akceptowana przez Trybunał Sprawiedliwości na gruncie art. 107 i 108 TFUE (wcześniej 87 i 88 TWE), zob. np. sprawa N 514/2001, Powszechne usługi bankowe „modernizacja systemu płatności świadczeń pieniężnych oraz zapewnienie dostępu do powszechnych usług bankowych poprzez urzędy pocztowe" - Zjednoczone Królestwo (Dz. U. C 186 z 6 sierpnia 2003 r., s. 17). 
W tym kontekście najistotniejszymi kwestiami będą te dotyczące adekwatności kapitałowej. Ze względu jednak na charakter opracowania nie sposób wskazać wszystkich rozwiązań w tym zakresie, a zatem dalsza analiza skupiać się będzie na wybranych, dyskusyjnych zagadnieniach w tej materii.

W przypadku banków spółdzielczych istotnym problemem jest zapewnienie odpowiednio wysokich funduszy własnych ${ }^{16}$. Pojawił się on już na samym początku przemian ustrojowych, a prawodawca wielokrotnie ingerował w ten aspekt działalności banków, wymuszając zmiany w tym zakresie ${ }^{17}$. Doprowadziły one w rezultacie do wzmocnienia kapitałowego, ale także do zmniejszenia liczby banków spółdzielczych (procesy konsolidacyjne). Przy czym docelowa wielkość funduszy własnych wyznaczona została przez prawodawcę unijnego, a do polskiego porządku prawnego została wprowadzona w związku z implementacją stosownej dyrektywy ${ }^{18}$.

Należy jednak mieć na uwadze, że problem wysokości funduszy własnych jest bezpośrednio związany z ich strukturą. W przypadku banków spółdzielczych fundusz podstawowy, będący jednym z zasadniczych elementów wpływających na wielkość funduszy własnych ${ }^{19}$, składa się z: wpłaconego funduszu udziałowego, funduszu zasobowego oraz funduszu rezerwowego. Wysokość funduszu udziałowego nie jest jednak stabilna, w związku z jego dwiema zasadniczymi cechami: zwrotności i zmienności ${ }^{20}$, co powoduje, że w przypadku spółdzielni, a ze względu na brak rozwiązań szczególnych w tym zakresie także banku spółdzielczego,

${ }_{16}$ Wskazać można, że choć obecnie zdecydowana większość b.s. ma fundusze własne powyżej $1 \mathrm{mln}$ euro, to jednak w zależności od kursu euro liczba ta ulega wahaniom i tak podczas gdy na dzień 31 lipca 2008 r. (kurs 3,20) wszystkie b.s. miały fundusze własne powyżej tego limitu, to już na 18 lutego 2009 r. (kurs 4,90) 21 b.s. nie spełniało ustawowego wymogu, na dzień 24 października 2011 r. (kurs 4,39) były to 4 b.s., za: M. Zaleska, Bank bankowi nierówny, „Głos Banków Spółdzielczych”, listopad-grudzień 2011, s. 41. Jednocześnie, zgodnie z szacunkami KNF, dalsze osłabienie złotego nie spowodowałoby istotnych zmian w tym zakresie, przy założeniu kursu 5,0 tylko 22 b.s. musiałyby pozyskać dodatkowy kapitał w wysokości 10-215 tys. euro, za: Raport o sytuacji banków w okresie I-IX 2011 r., UKNF, Warszawa 2011.

17 M.in. b.s. zostały zobowiązane do zwiększenia funduszy własnych do poziomu równowartości 300 tys. euro do dnia 31 grudnia 2000 r. (ustawa z dnia 9 kwietnia 1999 r. o zmianie ustawy o Bankowym Funduszu Gwarancyjnym oraz niektórych innych ustaw, Dz. U. Nr 40, poz. 399); u.f.b.s. określiła terminy ich osiągnięcia 300 tys. euro do końca 2001 r., 500 tys. euro do końca 2005 r., 1 mln euro do końca 2010 r. (ostatecznie skrócony do 31 grudnia 2012 r.).

${ }_{18}$ Chodzi tu o dyrektywę 2000/12/WE Parlamentu Europejskiego i Rady z dnia 20 marca 2000 r. odnoszącą się do podejmowania i prowadzenia działalności przez instytucje kredytowe, Dz. U. L 126 z 26 maja 2000 r., s. 1, zastąpioną przez dyrektywę Parlamentu Europejskiego i Rady 2006/48/WE z 14 czerwca 2006 r. w sprawie podejmowania i prowadzenia działalności przez instytucje kredytowe (wersja przeredagowana), Dz. Urz. UE L 177 z 30 czerwca 2006 r., s. 1 (dalej: dyrektywa 2006/48/WE).

${ }_{19}$ Wysokość funduszy podstawowych przekłada się na wysokość funduszy własnych także w sposób pośredni, albowiem fundusze podstawowe są istotnym czynnikiem dla określenia wysokości funduszy uzupełniających.

${ }^{20}$ Zgodnie z art. 1 Prawa spółdzielczego spółdzielnia jest dobrowolnym zrzeszeniem nieograniczonej liczby osób, o zmiennym składzie osobowym i zmiennym funduszu udziałowym. 
należy uznać za niedopuszczalne utworzenie funduszu udziałowego o określonej stałej wysokości ${ }^{21}$. Zmiana liczby członków wpływa więc bezpośrednio na wysokość tego funduszu ${ }^{22}$. Obecnie problem ten staje się szczególnie aktualny w związku z przygotowywaną zmianą przepisów w ramach CRD IV ${ }^{23}$, które precyzują kryteria, jakie powinny spełniać udziały banków spółdzielczych, aby mogły być zaliczone do funduszy własnych ${ }^{24}$. Ponownie zatem pojawia się kwestia wprowadzenia do polskiego porządku prawnego rozwiązań dotyczących np. przyznania prawa odmowy wykupu udziałów członkowskich w bankach spółdzielczych.

Rozważając kwestie możliwości zapewnienia stosowanej wysokości funduszy własnych, należy rozpatrzyć je także w kontekście nowelizacji u.f.b.s. ${ }^{25}$, która pozwoliła bankom spółdzielczym od 28 sierpnia 2009 r. zaciągać zobowiązania związane z emisją papierów wartościowych oraz regulacji u.p.b. stanowiących, że fundusze podstawowe mogą obejmować inne pozycje bilansu określone przez Komisję Nadzoru Finansowego (art. 127 ust. 2 pkt 2 lit. d u.p.b.), a w odniesieniu do funduszy uzupełniających - zobowiązania podporządkowane (art. 127 ust. 3 pkt 2 lit. b u.p.b.). Na mocy postanowień ustawy nowelizującej oraz w związku z uchwałą nr 314/2009 KNF $^{26}$ banki spółdzielcze dokonały emisji obligacji i podjęły starania, by mogły one powiększyć kapitał regulacyjny. Instrument ten

21 P. Zakrzewski, Majątek spółdzielni, Warszawa 2003, s. 37.

22 Mając świadomość tej słabości, dokonano zmiany kwalifikacji tego funduszu dla celów rachunkowych w rozporządzeniu regulującym międzynarodowe standardy rachunkowości (z elementu kapitału na zobowiązanie finansowe), co wywołało dyskusję, jak należy kwalifikować fundusz udziałowy z punktu widzenia norm ostrożnościowych (nadzorczych), bo w odróżnieniu od przyjętych w rachunkowości standardów, ustawa Prawo bankowe (ustawa z dnia 29 sierpnia 1997 r. Prawo bankowe, t.j. Dz. U. z 2002 r. Nr 72, poz. 665 ze zm. - dalej: u.p.b.) wyraźnie stanowi, że fundusz udziałowy jest zaliczany do funduszy własnych banków spółdzielczych, zob. A. Zalcewicz, Fundusz udziałowy jako składnik funduszy własnych banku spółdzielczego - wybrane problemy prawne, „Prawo Bankowe” 2008, nr 7-8, s. 116-130.

${ }^{23}$ Zgodnie z przyjętymi założeniami ramy prawne regulujące działalność bankową oraz zasady ostrożnościowe dla instytucji kredytowych mają zostać wyznaczone przez dyrektywę i rozporządzenie (chodzi tu o będące obecnie w fazie projektów: dyrektywę Parlamentu Europejskiego i Rady w sprawie warunków podejmowania i prowadzenia działalności przez instytucje kredytowe oraz nadzoru ostrożnościowego nad instytucjami kredytowymi i firmami inwestycyjnymi i zmieniającą dyrektywę 2002/87/WE Parlamentu Europejskiego i Rady w sprawie dodatkowego nadzoru nad instytucjami kredytowymi, zakładami ubezpieczeń oraz przedsiębiorstwami inwestycyjnymi konglomeratu finansowego, Bruksela, dnia 20 lipca 2011 r., KOM(2011) 453 wersja ostateczna 2011/0203 (COD) oraz rozporządzenie Parlamentu Europejskiego i Rady w sprawie wymogów ostrożnościowych dla instytucji kredytowych i firm inwestycyjnych, COM 20110452.

${ }^{24}$ Zob. szerzej M. Wilk, Udziały banków spółdzielczych jako składnik funduszy własnych w nowych regulacjach unijnych, „Głos Banków Spółdzielczych”, listopad-grudzień 2011, s. 38-39.

25 Ustawa z 1 lipca 2009 r. o zmianie ustawy o funkcjonowaniu banków spółdzielczych, ich zrzeszaniu się i bankach zrzeszających, Dz. U. Nr 127, poz. 1050 (dalej: ustawa nowelizująca).

${ }^{26}$ Uchwała nr 314/2009 Komisji Nadzoru Finansowego z 14 października 2009 r. w sprawie innych pozycji bilansu banku zaliczanych do funduszy podstawowych banku, ich wysokości, zakresu i warunków ich zaliczania do funduszy podstawowych banku, Dz. Urz. KNF z 2010 r. nr 1, poz. 8 (dalej: uchwała nr 314/2009 KNF). 
został wykorzystany jednak tylko krótkookresowo. Ze względu na przyjęcie dyrektywy tzw. CRD II ${ }^{27}$, która wprowadziła nowe rozwiązania prawne w zakresie tzw. instrumentów hybrydowych zaliczanych do funduszy podstawowych, konieczne stało się uchylenie ww. uchwały. W konsekwencji od 31 grudnia $2010 \mathrm{r}$. banki spółdzielcze nie mogą zaliczać do funduszy podstawowych nowo emitowanych instrumentów tego rodzaju, a środki z emisji obligacji długoterminowych, spełniające warunki określone w uchwale nr 314/2009 KNF i na podstawie decyzji KNF zaliczone do funduszy podstawowych na dzień 31 grudnia 2010 r., muszą spełniać warunki w zakresie maksymalnych kwot zaliczanych do funduszy podstawowych (ustalone w oparciu o art. 154 ust. 9 dyrektywy 2006/48/WE). Natomiast nadal jest możliwe zaliczenie zobowiązań z tytułu emisji obligacji jako zobowiązań podporządkowanych do funduszy uzupełniających (w kwocie i na zasadach ustalonych $\mathrm{w}$ decyzji KNF zgodnie z przepisami u.p.b. $)^{28}$.

Ważnym aspektem działalności banków spółdzielczych jest to, że w zdecydowanej większości funkcjonują one $\mathrm{w}$ zrzeszeniu ${ }^{29}$. Obecnie obowiązująca u.f.b.s. pozwoliła na większą swobodę w kształtowaniu sektora w tej materii ${ }^{30}$.

${ }^{27}$ Dyrektywa Parlamentu Europejskiego i Rady 2009/111/WE z 16 września 2009 r. zmieniająca dyrektywy 2006/48/WE, 2006/49/WE i 2007/64/WE w odniesieniu do banków powiązanych z centralnymi instytucjami, niektórych pozycji funduszy własnych, dużych ekspozycji, uzgodnień w zakresie nadzoru oraz zarządzania w sytuacji kryzysowej, Dz. Urz. UE L 302 z 17 listopada 2009 r., s. 97.

${ }^{28}$ Zob. szerzej A. Zalcewicz, Środki z emisji obligacji jako składnik funduszy własnych banków spółdzielczych - wybrane zagadnienia prawne, „Monitor Prawa Bankowego” 2011, nr 11, s. 50-63.

${ }^{29}$ Po transformacji ustrojowej koncepcja ta była realizowana w różny sposób, przy czym zmiany legislacyjne nie zawsze prowadziły do osiągania zamierzonych przez prawodawcę celów. Początkowo prawodawca przyznał BGŻ status banku państwowo-spółdzielczego, w którym zrzeszały się banki spółdzielcze, następnie na początku 1990 r. przyjęta została ustawa z dnia 20 stycznia 1990 r. o zmianach w organizacji i działalności spółdzielczości, Dz. U. 1990 r. Nr 6, poz. 36 ze zm., która w nowy sposób kształtowała również relacje między BGŻ a zrzeszonymi bankami. Na mocy jej postanowień przestał on być centralnym związkiem spółdzielczym, centralą organizacyjną i rewizyjną, w tym czasie część b.s.-ów zdecydowało o zrzeszeniu w BGŻ (na mocy zawartych umów cywilnoprawnych stał się on bankiem zrzeszającym), inne podjęły próbę tworzenia nowych struktur (powstały trzy banki zrzeszające: Gospodarczy Bank Wielkopolski SA w Poznaniu (dalej: GBW), Bank Unii Gospodarczej SA w Warszawie (dalej: BUG), Gospodarczy Bank Południowo-Zachodni SA w Warszawie (dalej: GBP-Z), uchwalenie ustawy restrukturyzacyjnej miało spowodować powstanie trójstopniowej struktury zrzeszeniowej, co jednak nie powiodło się i ostatecznie została przyjęta u.f.b.s.

${ }^{30}$ M.in. przez 12 lat jej obowiązywania zmniejszyła się z 12 do 2 liczba banków zrzeszających. W chwili uchwalenia u.f.b.s. bankami zrzeszającymi były: GBW, Lubelski Bank Regionalny SA w Lublinie, Warmińsko-Mazurski Bank Regionalny SA w Olsztynie, Małopolski Bank Regionalny SA w Krakowie, Pomorsko-Kujawski Bank Regionalny SA w Bydgoszczy, Bałtycki Bank Regionalny SA w Koszalinie, Mazowiecki Bank Regionalny SA w Warszawie, Dolnośląski Bank Regionalny SA we Wrocławiu, Rzeszowski Bank Regionalny SA w Rzeszowie, BUG, GBP-Z, BGŻ. Jednak na koniec 2001 r. 6 banków zrzeszających (ze względu na nieosiągnięcie progu kapitałowego w wysokości $10 \mathrm{mln}$ euro) podjęło decyzję o połączeniu z GBP-Z SA (od stycznia 2002 r. BPS), a w marcu 2002 r. decyzję taką podjął siódmy bank. Ustawa z dnia 27 czerwca 2003 r. o zmianie ustawy o funkcjonowaniu banków spółdzielczych, ich zrzeszaniu się i bankach zrzesza- 
Z punktu widzenia prowadzonych rozważań istotna jest jednak przyszła rola, jaką mają pełnić zrzeszenia i banki zrzeszające. Jak dalece ma sięgać współpraca w grupach bankowych? Czy przepisy powinny pozwolić na bardziej ścisłe powiązania kapitałowe? Czy możliwe i pożądane byłoby stworzenie rozwiązań pozwalających w ramach jednego zrzeszenia, na odrębnych zasadach, funkcjonować bankom spółdzielczym ściśle powiązanym kapitałowo i organizacyjnie oraz tym działającym w „luźniejszej” formule zrzeszeniowej?

\section{Podsumowanie}

Przez ostatnie 20 lat uwaga prawodawcy polskiego była skupiona na restrukturyzacji i umacnianiu sektora poprzez wprowadzenie stosownych wymogów kapitałowych, wymuszanie organizacji w spółdzielczym sektorze bankowym początkowo w systemie trójszczeblowym, a następnie dwuszczeblowym itp., z drugiej zaś strony sektor korzystał ze znacznej pomocy finansowej państwa i był postrzegany jako element słaby, mogący destabilizować system bankowy. Na plan dalszy zeszło określenie roli i zadań, jakie powinny spełniać tego rodzaju instytucje finansowe. Pomimo jednak braku regulacji w tym zakresie, banki spółdzielcze od kilku lat intensywnie próbują budować swój wizerunek jako banki społeczności lokalnych. Kryzys ostatnich lat pokazał jednak, że stały się one obecnie dość silne kapitałowo, a brak globalnych powiązań, uznawany dotychczas za słabość, okazał się czynnikiem wzmacniającym odporność i stabilność całego polskiego systemu bankowego. Banki spółdzielcze jako stabilizatory poszczególnych rynków krajowych mogą zatem pełnić ważną rolę na jednolitym rynku finansowym UE. W tym kontekście warto podkreślić, że mniejsze, pojedyncze banki spółdzielcze nie stanowią tzw. zagrożenia systemowego, co ma niebagatelne znaczenie dla utrzymywania równowagi rynkowej i odporności całego rynku finansowego ${ }^{31}$.

jących oraz ustawy o Narodowym Banku Polskim (Dz. U. z 2003 r. Nr 137, poz. 1303) wskazywała już na trzy banki regionalne: Gospodarczy Bank Wielkopolski SA - Spółdzielcza Grupa Bankowa w Poznaniu, BPS, MBR. Obecnie, od końca 2011 r., działają dwa banki zrzeszające: BPS i SGB-Bank SA w Poznaniu.

${ }^{31}$ Problem istnienia ważnych systemowo banków w ujęciu europejskim i ich wpływu na stabilność finansową jest coraz szerzej dyskutowany na forum UE i obecnie trwają prace nad przygotowaniem dyrektywy odnoszącej się do SIFIs (Systematically Important Financial Institutions), także polski nadzorca podjął kroki mające na celu wprowadzenie klasyfikacji pozwalającej na wskazanie banków tzw. znaczących, zob. uchwała nr 258/2011 KNF z dnia 4 października 2011 r. w sprawie szczegółowych zasad funkcjonowania systemu zarządzania ryzykiem i systemu kontroli wewnętrznej oraz szczegółowych warunków szacowania przez banki kapitału wewnętrznego i dokonywania przeglądów procesu szacowania i utrzymywania kapitału wewnętrznego oraz zasad ustalania polityki zmiennych składników wynagrodzeń osób zajmujących stanowiska kierownicze w banku, Dz. Urz. KNF nr 11, poz. 42, co w dalszej kolejności będzie prawdopodobnie prowadzić do różnicowania wymogów regulacyjnych. 
Odnosząc się do zmian w obszarze prawa finansowego, naturalnym jest, że uległo ono ogromnym przeobrażeniom, w tym jego część odnosząca się do funkcjonowania banków spółdzielczych, albowiem jest to oczywistą konsekwencją przemian ustrojowych. Jednak w przypadku banków spółdzielczych okres ostatnich 20 lat wskazuje, że musiały one bardzo intensywnie przystosowywać się do ciągłych zmian legislacyjnych. W sposób szczególny doświadczają one niestabilności prawa i konieczności ciągłego dostosowywania przepisów krajowych, które to zjawiska nasiliły się jeszcze w związku z przystąpieniem Polski do UE i niezbędnym harmonizowaniem tych przepisów z unijnymi. Zmienia się też rola prawodawcy krajowego w obszarze kształtowania prawa. Nie jest on już w tym zakresie niezależny i coraz większe znaczenie ma obecnie jego współudział w decydowaniu o kształcie regulacji europejskich i odpowiednie modyfikowanie prawa krajowego, tak by było ono efektywnym narzędziem realizacji jego koncepcji. Brak aktywnego uczestnictwa w tym obszarze czy inicjatywy legislacyjne podejmowane bez odnoszenia się do kierunków wyznaczanych na szczeblu UE muszą być bowiem korygowane w momencie przyjęcia innych, unijnych rozwiązań. Należy zatem postulować, by polski prawodawca ze szczególną uwagą pochylił się nad sprawami obecnie dyskutowanymi na forum europejskim, takimi jak: możliwość zróżnicowanego poziomu wymogów regulacyjnych dla banków i przygotowania stosownych propozycji zmian legislacyjnych w zakresie udziałów członkowskich banków spółdzielczych, w tym możliwej nowelizacji Prawa spółdzielczego czy też przyjęcia nowej ustawy w tym zakresie.

Analizując obecną rolę banków spółdzielczych, należy mieć na względzie, że aktualnie wiele pierwotnie istniejących przyczyn tworzenia $i$ istnienia tego typu spółdzielni, jak zapewnienie dostępu do usług finansowych członków spółdzielni, straciło na znaczeniu. Dezintegracja społeczności lokalnej, a także bierność charakteryzująca poczynania, a raczej ich brak w podejmowaniu inicjatyw samopomocowych przy wzroście wymogów prawnych dla tworzenia i funkcjonowania tych podmiotów sprawia, że banki te nie są alternatywą dla pozyskania środków przez członków społeczności w drodze kreowania tego typu spółdzielni i aktywnego uczestnictwa $\mathrm{w}$ ich właścicielskim kierowaniu. Wprowadzane po transformacji ustrojowej regulacje prawne spowodowały, że banki te spełniają normy bezpieczeństwa, ale przestały być elementem aktywnego udziału członków społeczeństwa w dążeniu do zaspokajania własnych potrzeb finansowych. Można by też przyjąć, że przyczyną tego stanu rzeczy są zaszłości historyczne wpływające na sposób postrzegania działalności spółdzielczej przez społeczeństwo jako kojarzonej z poprzednim ustrojem i nieprzystającej do nowych realiów. Jednakże, jak pokazuje intensywny rozwój spółdzielczych kas oszczędnościowo-kredytowych, kształt regulacji normatywnych może uaktywniać bądź dezaktywować te inicjatywy. Problem legislacyjny sięga jednak głębiej, wynika on przede wszystkim z braku koncepcji co do organizacji sektora spółdzielczego jako całości. Ustawa Prawo spółdzielcze obowiązuje od 30 lat i jest aktem nieprzystającym do obec- 
nych uwarunkowań. Od lat podejmowane próby przyjęcia nowych regulacji w tym zakresie kończyły się niepowodzeniem. Tymczasem konieczne jest nowe podejście do wielu zagadnień prawa spółdzielczego, jak chociażby wskazywane kwestie związane z udziałami i funduszem udziałowym, zwłaszcza w kontekście zmian normatywnych, planowanych na szczeblu unijnym w CRD IV.

Banki spółdzielcze jednak chcą i mogą nadal pełnić rolę podmiotów działających na rzecz integracji finansowej społeczeństwa, aczkolwiek konieczna jest zmiana podejścia prawodawcy i podjęcie aktywnych działań w tym zakresie, jak ma to miejsce w innych państwach UE.

Na koniec warto zauważyć, że rozważenia wymagałaby również możliwość tworzenia banków spółdzielczych przez JST i powstania tym samym banków samorządowych, działających na rzecz swoich członków - wspólnot samorządowych, a tym samym na rzecz rozwoju społeczeństwa lokalnego. 